\title{
STUDIES OF ANTERIOR PITUITARY TISSUE IN VITRO: EFFECTS OF INSULIN AND EXPERIMENTAL DIABETES MELLITUS UPON CARBOHYDRATE METABOLISM *
}

\author{
BY CHARLES J. GOODNER $†$ AND NORBERT FREINKEL
}

(From the Thorndike Memorial Laboratory and Second and Fourth (Harvard) Medical

Services, Boston City Hospital, and the Department of Medicine, Harvard

Medical School, Boston, Mass., and the Howard Hughes Medical

Institute, Miami, Fla.)

(Submitted for publication June 24, 1960; accepted October 7, 1960)

Since the classical experiments of Houssay and Biasotti (1), Evans, Meyer, Simpson and Reichert (2), Young (3), and Long and Lukens (4), the diabetogenic potential of pituitary hormones has been amply documented (5). However, the metabolism of glucose by the pituitary has received but little examination (6-9), and the authors have been unable to find any pulblished studies of the hormonal determinants of hypophyseal carbohydrate economy. Because of the potential contribution of these factors to the endocrine function of the pituitary, experiments were initiated to define the role of insulin. The studies have demonstrated that the assimilation and disposition of glucose by surviving preparations of anterior pituitary from normal rats and beef may be enhanced by insulin in vitro. Moreover, it has been shown that glucose metabolism is significantly reduced in anterior pituitaries excised from rats rendered insulin-deficient by total pancreatectomy or alloxanization, and that these hypophyseal derangements can be prevented by replacement therapy with insulin in vivo.

\section{METHODS}

\section{Preparation of tissues for incubation}

A. Calf pituitary. Pituitary glands were obtained from male and female calves at the abattoir within 5 to 15 minutes after the death of the animals by exsanguination. The whole glands, left in their fascial investments, were placed in plastic bags and transported to the labora-

* This investigation was supported in part by Research Grant A-1571 and Training Grant 2A-5060, National Institute of Arthritis and Metabolic Diseases, Bethesda, Md. Portions of this work have been published in abstract form: Clin. Res. 1960, 8, 25 ; J. clin. Invest. 1960, 39, 991.

$\dagger$ Research Fellow of the National Institute for Arthritis and Metabolic Diseases, U. S. Public Health Service. tory in an insulated container at a temperature of 4 to $10^{\circ} \mathrm{C}$. Upon arrival at the laboratory, the capsules and adherent diaphragma sellae were removed with scissors and the glands were separated into anterior (AP) and posterior (PP) lobes by blunt dissection in KrebsRinger bicarbonate (KRB) at room temperature. A definite cleavage plane between the two portions (AP and PP) facilitated separation. This was documented histologically, and in calf the pars intermedia was included with the AP.

Slices of 0.7 to $1.0 \mathrm{~mm}$ thickness were prepared freehand from calf AP which was held loosely between plastic blocks and supported on filter paper moistened with KRB. Although it was appreciated that gaseous diffusion into the center of the slice would probably be limited, thick slices were utilized for this study on the premise that insulin responsiveness in vitro might be enhanced by minimizing the cut surface area per unit weight of tissue. While this work was in progress, a report appeared which supported this assumption in studies of the effect of insulin upon rat spinal cord in vitro (10). Care was taken to pair the slices in control and experimental vessels with respect to gland topography since the various adenohypophyseal cell types are not uniformly distributed in the calf pituitary $(11,12)$. Calf AP was divided into hemilobes which were cut into four slices. The two slices representing the outer layers of the hemilohes were smaller in diameter, whereas two larger slices were derived from the central portion. To fill four incubation vessels from a single $\mathrm{AP}$, one outer and one inner slice from opposite hemilobes were introduced into each vessel. The total calf AP averaged $393 \pm 27 \mathrm{mg}^{1}$ and tissue weights in AP vessels ranged from 76 to $140 \mathrm{mg}$.

B. Rat pituitary. Male albino rats weighing 200 to $350 \mathrm{~g}$ were obtained from the Charles River Breeding Laboratories (Sprague-Dawley descendants) and maintained in this laboratory on Purina laboratory pellets. In all experiments, pituitaries were excised within 1 minute following sacrifice of animals by stunning and decapitation. Individual glands were placed directly in $\mathrm{KRB}$ at room temperature and $\mathrm{AP}$ and $\mathrm{PP}$ were teased apart with the aid of a dissection microscope (20X). Histological examination demonstrated complete separa-

1 Mean \pm standard error (SE). 


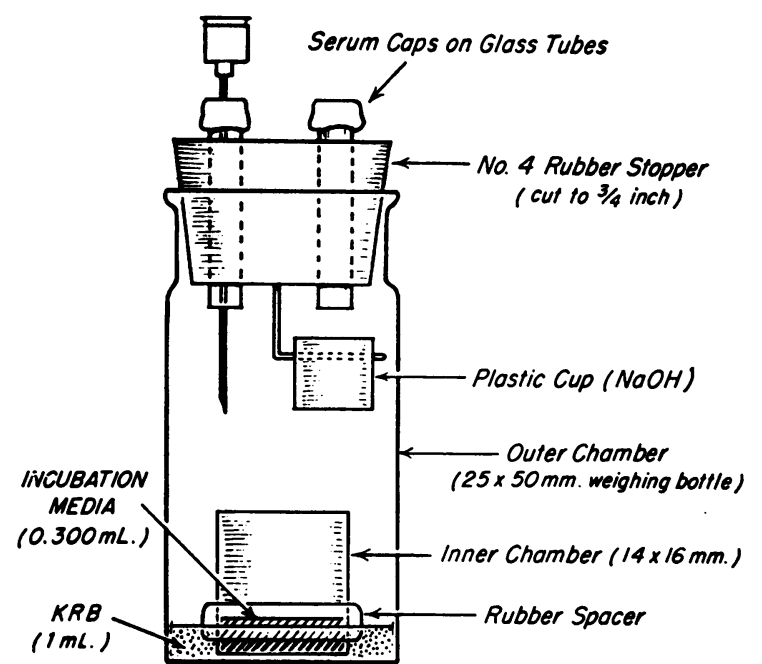

Fig. 1. MOdIFIEd REACTION VESSEL FOR INCUBATION OF SINGLE RAT ANTERIOR PItUitary. For description, see text.

tion of AP and PP. The pars intermedia was present as adherent fragments about the posterior lobe.

For studies of pituitaries from normal fed donor rats, tissues from multiple animals were pooled. Each AP was divided at the midline with a sharp blade and each hemilobe was $a$ ) gently rolled on gauze, $b$ ) weighed on a $10 \mathrm{mg}$ torsion balance accurate to $\pm 0.01 \mathrm{mg}$, and $c$ ) placed in either a "control" or "experimental" vessel (see below) for incubation. To fill two such paired vessels, a total of 6 to 10 rats was sacrificed serially. Thus, individual vessels contained the equivalent of 3 to 5 anterior pituitaries ( 16.4 to $20.0 \mathrm{mg}$ ). In paired vessels, the tissue weights were within $\pm 1 \mathrm{mg}$. On the other hand, for studies of hypophyseal carbohydrate metabolism in rats which had been subjected to experimental diabetes or other manipulations prior to sacrifice (see below), single anterior pituitaries were incubated individually. Herein, the intact AP was employed and hemisection was not instituted.

\section{Incubation technique and media composition}

In all of the studies, tissues were incubated for 3 hours at $38^{\circ} \mathrm{C}$ in a Dubnoff metabolic shaker (shaking rate 96 cycles per minute). The suspending medium consisted of $\mathrm{KRB}, \mathrm{pH} 7.4$, supplemented with unlabeled (National Bureau of Standards) and $\mathrm{C}^{\mathbf{1 4}}$-labeled glucose to final concentrations of 1.0 to $2.0 \mathrm{mg}$ glucose per $\mathrm{ml}$, and 0.8 to $3.0 \mu \mathrm{c} \mathrm{C} \mathrm{C}^{14}$ per $\mathrm{ml}$. The gas phase consisted of 95 per cent $\mathrm{O}_{2}, 5$ per cent $\mathrm{CO}_{2}$. The various preparations of radioactive glucose, [i.e., labeled uniformly (C-U); or in the first (C-1) or sixth (C-6) carbon atoms] were obtained chromatographically pure from several commercial sources. ${ }^{2}$ For studies of insulin action in vitro

${ }^{2}$ Glucose-U-C ${ }^{14}$ purchased from Tracerlab and New England Nuclear Corporation, Boston, Mass. Glucose$1-C^{14}$ and glucose-6-C $C^{14}$ purchased from Nuclear-Chicago, III. upon calf slices and pooled hemisected AP from normal rats, media were further supplemented with either $1.0 \mathrm{U}$ per $\mathrm{ml}(40 \mu \mathrm{g})$ of "glucagon-free" crystalline beef insulin $^{3}$ ("experimental vessels") or $40 \mu \mathrm{g}$ per $\mathrm{ml}$ of crystalline bovine albumin 4 ("control vessels"). In a few instances, albumin was omitted from the "control" systems (see below).

Incubations were conducted in $25 \times 50 \mathrm{~mm}$ glass weighing bottles sealed with a rubber stopper (13). Two rubber-capped glass vents in the stopper permitted introduction of solutions or gases into the sealed vessels through needles. The stoppers also supported small plastic cups into which $\mathrm{NaOH}$ was introduced at the end of incubation for collection of $\mathrm{C}^{14} \mathrm{O}_{2}$ as outlined below. In the experiments with calf pituitary slices and pooled hemisected rat AP, the total volume of incubation medium consisted of $1.2 \mathrm{ml}$ which was directly introduced into the weighing bottle. For incubation of individual rat anterior pituitaries, the flasks were modified as shown in Figure 1. A small glass cup measuring $14 \times 16 \mathrm{~mm}$ (inner chamber, Figure 1) was placed in the larger bottle. A rubber ring (cut from rubber tubing) was slipped around the small vessel to prevent capillary migration of fluid between the inner and outer chambers. Intact single adenohypophyses were incubated in the inner chamber and suspended in a total volume of $0.3 \mathrm{ml} \mathrm{KRB}$. To minimize evaporative losses in this system and to promote conduction of heat from the Dubnoff bath to the inner chamber, an additional $1.0 \mathrm{ml}$ of isosmotic $\mathrm{KRB}$ was placed into the outer chamber.

Incubation was terminated by introducing $0.2 \mathrm{ml} 5 \mathrm{~N}$ $\mathrm{NaOH}$ into the plastic cups, and thereafter either $a$ ) introducing $0.1 \mathrm{ml} 1 \mathrm{~N} \mathrm{HCl}$ directly into the $1.2 \mathrm{ml}$ of suspending medium, or $b$ ) introducing $1.0 \mathrm{ml}$ of $0.03 \mathrm{~N}$ $\mathrm{HCl}$ in isotonic $\mathrm{NaCl}$ into the inner chamber and $0.1 \mathrm{ml}$ $1 \mathrm{~N} \mathrm{HCl}$ into the outer chamber. Two hours was allowed for evolution of $\mathrm{C}^{14} \mathrm{O}_{2}$ after acidification of the media.

\section{General analytical techniques}

A. Glucose. Protein-free filtrates were prepared from plasma or whole blood by precipitation with $\mathrm{Ba}(\mathrm{OH})_{2}+$ $\mathrm{ZnSO}_{4}$ (14). Plasma was obtained from heparinized blood collected from the severed neck vessels at sacrifice. In some experiments, whole blood was obtained from the tail vein prior to sacrifice. The filtrates were analyzed for glucose by the enzymatic colorimetric method of Huggett and Nixon (15). Aliquots of suspending media which had been incubated both with and without tissues were similarly precipitated with $\mathrm{Ba}(\mathrm{OH})_{2}+\mathrm{ZnSO}_{4}$, and the protein-free filtrates were employed for duplicate assay of glucose concentration.

B. Radioactive carbon dioxide. $\quad \mathrm{C}^{14} \mathrm{O}_{2}$ evolved during the incubation period was precipitated quantitatively with

${ }^{3}$ Crystalline zinc insulin (lot no. 499667) assaying $25 \mathrm{U}$ per $\mathrm{mg}$ was generously provided by Dr. O. K. Behrens and Dr. C. W. Pettinga of Eli Lilly Company.

4 Armour lot no. T 68204. 
barium chloride from sodium hydroxide and assayed in duplicate as barium carbonate, as described previously (16).

C. Glycogen $C^{14}$. At the end of incubation, calf AP slices were placed directly in $1 \mathrm{ml}$ of 30 per cent $\mathrm{KOH}$ and $1 \mathrm{ml}$ of 95 per cent enthanol and autoclaved for one hour (at $15 \mathrm{lbs} 120^{\circ} \mathrm{C}$ ). Carrier glycogen, 12.0 $\mathrm{mg}$, was added and glycogen was precipitated by the method of Good, Kramer and Somogyi (17). The glycogen was precipitated a second time and then dissolved in $2.5 \mathrm{ml}$ of distilled water for 24 hours of dialysis at $4^{\circ}$ $\mathrm{C}$ against three changes of $100 \mathrm{vol}$ of $0.001 \mathrm{M}$ phosphate buffer ( $\mathrm{pH} 7.4)$. The dialyzed glycogen solutions were then decanted and duplicate $1.0 \mathrm{ml}$ aliquots were deposited on weighed cup planchets for radioactive assay in a gas-flow counter. Mass absorption corrections were applied.

The dialysis method was validated for calf anterior pituitary by comparing the specific activity of glycogen obtained by this method with the specific activity of thrice recrystallized glucosazones, prepared from an acid hydrolysate of the parent glycogen solution. In four experiments, the glucosazone and dialysis methods yielded similar results. Control studies also indicated that glycogen radioactivity was not measurably contaminated with cerebrosides (18).

D. Lipid $C^{14}$. In experiments with pooled AP tissue from normal rats, total chloroform: methanol-extractable lipids $\left(\mathrm{CHCl}_{3}: \mathrm{MeOH}\right.$ lipid $\left.\mathrm{C}^{14}\right)$ (19) were obtained for radioactive assay as follows. After incubation, the tissues were placed directly into chloroform: methanol $2: 1$ (vol/vol) and homogenized. The mixture was centrifuged, the supernatant fluid decanted, and the sediment re-extracted in warm $\left(60^{\circ} \mathrm{C}\right)$ chloroform: methanol. The combined extracts were washed three times with isotonic $\mathrm{NaCl}$ (19) and assayed at infinite thinness on cup planchets in a gas-flow counter. For calf AP and a small number of experiments with rat AP, tissue lipids were fractionated into nonsaponifiable lipids, and long chain fatty acids (20). The nonsaponifiable lipid extract was reduced in volume and quantitatively plated for radioactive assay in a micromil-window gas-flow counter. The fatty acids were evaporated under reduced pressure and redissolved in toluene, 0.4 per cent 2,5-diphenyloxazole (PPO) and 0.005 per cent 1,4-bis-2-(5-phenyloxazolyl)-benzene (POPOP $)^{5}$ solution for radioactive assay in a Packard Tri-Carb liquid scintillation counter. ${ }^{6}$

\section{Expression of results}

Net glucose assimilation in micrograms of glucose per milligram of tissue was calculated from the initial tissue wet weight and the total micrograms of glucose disappearing from the media during 3 hours of incubation. The latter value was calculated on the basis of the difference between the final content of glucose in ex-

\footnotetext{
5 Purchased from Pilot Chemical Co., Watertown, Mass.

6 Packard Instrument Company, Inc., La Grange, I1l.
}

perimental vessels and in vessels which had heen incubated without tissuc.

Disposition of glucose-( ${ }^{14}$ was expressed as micrograms of glucose- $\mathrm{C}^{14}$ per milligram of initial wet tissue weight and calculated on the basis of the specific activity of the glucose in the initial suspending medium and the recovered $\mathrm{C}^{\mathbf{1 4}}$. Initial specific activity was determined for each experiment by separate chemical and radioactive assay of the media in duplicate blank vessels. Sufficient counts were collected to reduce random counting error to less than \pm 1 per cent for standards, $\mathrm{C}^{14} \mathrm{O}_{2}$, and glycogen- $\mathrm{C}^{14}$, and to less than \pm 3 per cent for the lipid fractions. Since the authors were unable to demonstrate glucose-6phosphatase activity in calf anterior pituitary tissue (21), the values for glucose assimilation and initial specific activity of the medium could be employed to assess net assimilation of glucose radioactivity.

The statistical significance of the effects of insulin in vitro was evaluated by testing the ratios of the observed values in paired "control" and "experimental" vessels of individual experiments for deviation from a ratio of unity. The common logarithms of the ratios were employed and Student's $t$ values were calculated from the mean and standard error of the mean of the $\log$ form of these ratios (22). Such analysis of relative changes effected by insulin made it possible to pool data from multiple experiments conducted with varying concentrations of glucose in the medium.

TABLE I

The effect of insulin in vitro upon glucose assimilation by slices of calf anterior pituitary

Reaction mixture: 76 to $140 \mathrm{mg}$ tissue slices suspended in $1.2 \mathrm{ml} \mathrm{KRB}$ containing $2.0 \mathrm{mg}$ glucose per $\mathrm{ml}$ and either $1.0 \mathrm{U}, 40 \mu \mathrm{g}$, insulin per $\mathrm{ml}(+)$ or $40 \mu \mathrm{g}$ crystalline bovine albumin per $\mathrm{ml}(-)$ Incubation: 3 hours, $38^{\circ} \mathrm{C}$.

\begin{tabular}{rrrc} 
& \multicolumn{2}{l}{ Glucose assimilation } & \\
\cline { 2 - 4 } Gland & $(-)$ & $(+)$ & Insulin effect \\
\hline & \multicolumn{2}{c}{$\mu g / m g$} & $+/-\times 100^{*}$ \\
1 & 3.28 & 3.65 & 111.3 \\
2 & 4.07 & 4.79 & 117.7 \\
3 & 5.69 & 7.25 & 127.4 \\
4 & 4.73 & 7.94 & 167.9 \\
5 & 8.49 & 7.58 & 89.3 \\
6 & 6.20 & 7.81 & 126.0 \\
7 & 5.50 & 7.01 & 127.5 \\
8 & 5.44 & 6.35 & 116.7 \\
9 & 1.34 & 2.08 & 155.2 \\
10 & 5.74 & 5.93 & 103.3 \\
11 & 1.53 & 1.49 & 97.4 \\
12 & 3.27 & 5.00 & 152.9 \\
13 & 3.76 & 5.31 & 141.2 \\
14 & 4.76 & 4.88 & 102.5 \\
15 & 5.00 & 6.48 & 129.6 \\
16 & 2.97 & 4.00 & 134.7 \\
17 & 3.79 & 4.30 & 113.5 \\
& & & \\
& & &
\end{tabular}

* Insulin effect: results observed in insulin-containing systems $(+)$ expressed as a percentage of the values in control (-) vessels. By this convention, 100 denotes no effect. 
TABLE, II

Metabolism of glucose-U-C $C^{14}$ by culf anterior pituitary

Reaction mixture: as in Table $I$; glucose $2.0 \mathrm{mg}$ per. $\mathrm{ml}$ labeled with 0.8 to $1.2 \mu \mathrm{c}$ glucose-U-C ${ }^{14}$ per $\mathrm{ml}$ Incubation: as in Table I.

\begin{tabular}{|c|c|c|c|c|c|c|c|c|}
\hline \multirow{2}{*}{$\begin{array}{c}\text { Gland } \\
\text { no.* }\end{array}$} & \multicolumn{4}{|c|}{$\mathrm{CO}_{2} \begin{array}{c}\text { Glucose-U-C14 } \\
\text { Glycogen }\end{array}$} & \multicolumn{2}{|c|}{$\begin{array}{l}(\mu \mathrm{g} / \mathrm{mg}) \text { to: } \\
\text { Non-sap. lipid }\end{array}$} & \multicolumn{2}{|c|}{ Fatty acid } \\
\hline & $(-)$ & $(+)$ & $(-)$ & $(+)$ & $(-)$ & $(+)$ & $(-)$ & $(+)$ \\
\hline 6 & 1.12 & 1.35 & 0.72 & 1.01 & 0.0028 & 0.0040 & 0.025 & 0.4 \\
\hline 7 & 0.76 & 1.17 & 0.64 & 0.91 & 0.0024 & 0.0045 & 0.036 & 0.042 \\
\hline 8 & 0.81 & 1.17 & 0.77 & 0.83 & 0.0027 & 0.0040 & 0.044 & 0.058 \\
\hline 9 & 0.24 & 0.33 & 0.14 & 0.21 & 0.0006 & 0.0007 & 0.0026 & 0.0031 \\
\hline 10 & 0.85 & 0.85 & 0.76 & 0.82 & 0.0032 & 0.0029 & 0.021 & 0.031 \\
\hline 11 & 0.41 & 0.36 & 0.20 & 0.21 & 0.0011 & 0.0008 & 0.0048 & 0.0061 \\
\hline
\end{tabular}

* Gland numbers as in Table I. Values for total glucose assimilation from the suspending medium in the absence $(-)$ and presence $(+)$ of insulin are shown in Table I.

\section{RESULTS}

I. Effects of added insulin upon carbohydrate metabolism of surviving anterior pituitary tissue from normal animals

$A$. Calf. Seventeen separate experiments were performed in which slices of adenohypophyses from slaughterhouse calves were incubated for 3 hours in $1.2 \mathrm{ml}$ of media containing $2 \mathrm{mg}$ glucose per $\mathrm{ml}$ (Table I). Under these conditions, net assimilation of glucose from the suspending media averaged $4.44 \pm 0.43 \mu \mathrm{g}$ per $\mathrm{mg}$ tissue in "control" vessels. With 13 of the 17 glands, glucose uptake was increased at least 10 per cent above control values by the addition of $1.0 \mathrm{U}$ of insulin per $\mathrm{ml}$. For all experiments, the induced augmentation of glucose assimilation averaged 24.4 per cent and was highly significant $(p=0.001$, Table I).

In 12 of the 17 glands, intracellular disposition of some of the assimilated glucose was evaluated with glucose-C $\mathrm{C}^{14}$. Uniformly labeled glucose was used in six instances (i.e., glands 6 through 11). Herein, $\mathrm{C}^{14} \mathrm{O}_{2}$ was employed as an index of oxidative degradation, and anabolic utilization was assessed on the basis of the incorporation of radioactivity into glycogen, nonsaponifiable lipids, and fatty acids. Results are summarized in Table II. In the four experiments in which insulin promoted glucose uptake (i.e., 6 through 9 ), oxidative decarboxylation, glycogenesis and lipogenesis were also augmented. Contrariwise, in glands 10 and 11 , in which insulin did not significantly affect the assimilation of glucose, uniform effects upon the disposition of glucose- $\mathrm{U}-\mathrm{C}^{14}$ were not observed.

In six experiments (i.e., glands 12 through 17 ), differentially labeled preparations of radioactive glucose were employed ('Table III). The existence of the phosphogluconic acid pathway for glucose oxidation in anterior pituitary tissue was demonstrated by the routine evolution of greater quantities of $\mathrm{C}^{14} \mathrm{O}_{2}$ from glucose labeled in the first carbon than from glucose labeled in the sixth position. In control vessels, C-1/C- 6 ratios for $\mathrm{C}^{14} \mathrm{O}_{2}$ averaged $2.04 \pm 0.17$. Addition of insulin caused an average 14.8 per cent increase in $\mathrm{C}^{14} \mathrm{O}_{2}$ from glucose-1- $\mathrm{C}^{14}(\mathrm{p}=0.1)$ and an average 50.9 per cent increase in $\mathrm{C}^{14} \mathrm{O}_{2}$ from glucose-6$\mathrm{C}^{14}(\mathrm{p}=0.01$, Table III $)$.

B. Rats. Eighteen experiments were performed with pooled tissues from normal fed rats. Paired groups of hemisected anterior pituitaries were incubated for 3 hours in $1.2 \mathrm{ml}$ of media containing 1.0 to $2.0 \mathrm{mg}$ of glucose per $\mathrm{ml}$ and 1.1 to $2.6 \mu \mathrm{c}$ glucose-U-C ${ }^{14}$ (Table IV). Results from all experiments were combined in order to assess the statistical significance of changes effected by supplementing suspending media with $1.0 \mathrm{U}$ of insulin per $\mathrm{ml}$. In the presence of insulin, the mean assimilation of glucose was 16.7 per cent greater than control values $(p=0.02$, Table IV). Concomitantly, the evolution of $\mathrm{C}^{14} \mathrm{O}_{2}$ from glucose$\mathrm{U}-\mathrm{C}^{14}$ was increased an average of 6.4 per cent $(p=0.02)$ and the mean incorporation of radioactivity into total chloroform-methanol extractable lipids was augmented 19.0 per cent $(\mathrm{p}=0.01)$.

\section{Carbohydrate metabolism of surviving anterior pituitary tissue from insulin-deficient rats}

In this series of experiments, rats were subjected to various manipulations in vivo designed

TABLE III

Metabolism of glucose-1-C $C^{14}$ and glucose- $6-C^{14}$ by calf anterior pituitary

\begin{tabular}{|c|c|c|c|c|c|c|}
\hline \multicolumn{7}{|c|}{$\begin{array}{l}\text { Reaction mixture: as in Table I; glucose } 2.0 \mathrm{mg} \text { per ml labeled with } 1.1 \\
\text { and } 1.3 \mu \mathrm{c} \text { per ml of glucose-1- } \mathrm{C}^{14} \text { and glucose- } 6-\mathrm{C}^{14} \text {, respectively. } \\
\text { Incubation: as in Table I. }\end{array}$} \\
\hline \multirow{3}{*}{$\begin{array}{l}\text { Gland } \\
\text { no.* }\end{array}$} & \multicolumn{3}{|c|}{ Control (-) } & \multicolumn{3}{|c|}{ Insulin ( + ) } \\
\hline & \multicolumn{2}{|c|}{$\mathrm{C}^{14} \mathrm{O}_{2}(\mu \mathrm{g} / \mathrm{mg})$} & \multirow{2}{*}{$\begin{array}{c}\text { Ratio } \\
\mathrm{C}-1 / \mathrm{C}-6\end{array}$} & \multicolumn{2}{|c|}{$\mathrm{C}^{{ }^{14} \mathrm{O}_{2}(\mu \mathrm{g} / \mathrm{mg})}$} & \multirow{2}{*}{$\begin{array}{c}\text { Ratio } \\
\text { C-1/C-6 }\end{array}$} \\
\hline & $C-1$ & C-6 & & $\mathrm{C}-1$ & C-6 & \\
\hline 12 & 2.04 & 1.34 & 1.52 & 2.74 & 2.39 & 1.14 \\
\hline 13 & 2.64 & 1.55 & 1.70 & 3.31 & 2.10 & 1.58 \\
\hline 14 & 1.62 & 0.686 & 2.37 & 1.77 & 1.12 & 1.58 \\
\hline 15 & 1.90 & 0.811 & 2.34 & 2.02 & 1.57 & 1.29 \\
\hline 16 & 1.01 & 0.552 & 1.83 & 1.49 & 0.794 & 1.88 \\
\hline 17 & 1.68 & 0.679 & 2.48 & 1.34 & 0.737 & \\
\hline \multicolumn{6}{|c|}{ Mean $\pm S E \quad 2.04 \pm 0.17$} & $1.55 \pm 0.12$ \\
\hline \multicolumn{7}{|c|}{$\begin{array}{l}\mathrm{C}-1(-) \text { vs } \mathrm{C}-1(+) \mathrm{p}>0.1 \\
\mathrm{C}-6(-) \text { vs } C-6(+) \mathrm{p}<0.01 \\
\mathrm{C}-1 / \mathrm{C}-6(-) \text { vs } \mathrm{C}-1 / \mathrm{C}-6(+) \mathrm{p}<0.02\end{array}$} \\
\hline
\end{tabular}

* Gland numbers as in Table I. 
TABLE IV

The effect of insulin in vitro upon the metabolism of glucose- $U$ - $C^{14}$ by rat anterior pituitary

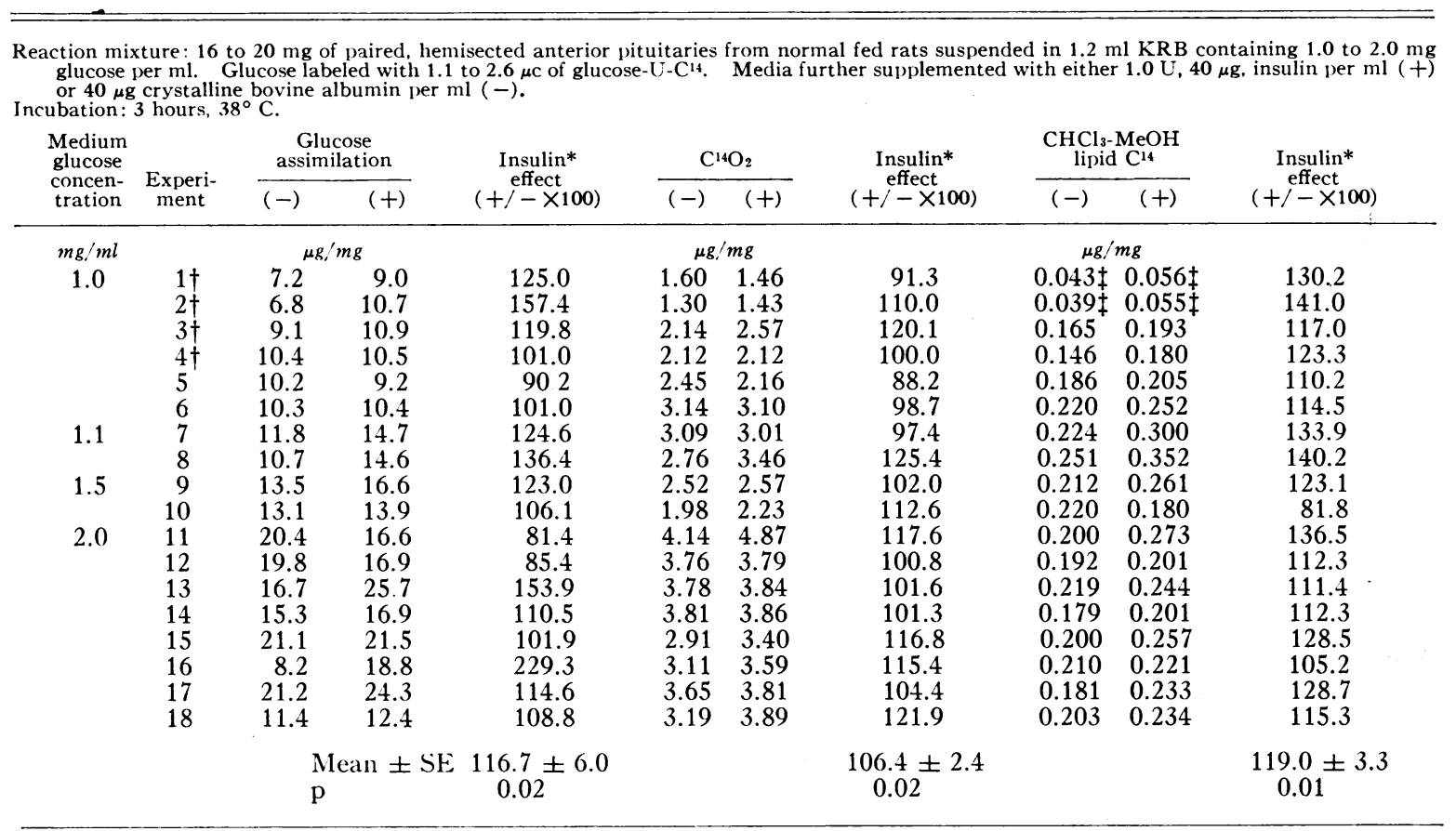

* Insulin effect : results observed in insulin-containing systems $(+)$ expressed as a percentage of the values in control vessels $(-)$.

$\dagger$ Albumin omitted from control vessels.

$\ddagger$ Fatty acids.

to alter levels of circulating insulin. Thereafter, anterior pituitaries from individual rats were excised and separately incubated in $0.3 \mathrm{ml} \mathrm{KRB}$ containing $2.0 \mathrm{mg}$ glucose per $\mathrm{ml}, 3.0 \mu \mathrm{c}$ glucose$\mathrm{U}-\mathrm{C}^{14}$ per $\mathrm{ml}$ and no supplemental albumin or insulin. Adenohypophyses were examined in the intact state, and were not hemisected as in the above studies with pooled tissues from normal animals.

A. Rats with total pancreatectomy. Total ( 99.5 per cent) pancreatectomy was performed as described by Scow (23) upon rats weighing between 220 and $330 \mathrm{~g}$ and fasted from 12 to 20 hours prior to operation. Comparable rats, matched by weight in individual experiments, were subjected to either: $a$ ) sham pancreatectomy, consisting of laparotomy and exposure of stomach, liver, duodenum and spleen to air for a similar period of time; or $b$ ) partial pancreatectomy, removing only the "first portion" (23) of the pancreas.

Additional control groups were prepared by removing a short section of bile duct to produce bile peritonitis or by removing $4.0 \mathrm{ml}$ of blood from the aorta and injecting this blood into the peritoneal cavity to produce conditions of intraabdominal hemorrhage with shock.

All rats were given $5.0 \mathrm{ml}$ of saline and 12,000 $U$ of crystalline penicillin subcutaneously after operation. The rats were maintained in individual metabolic cages until sacrifice, 20 hours following surgery. At that time, anterior pituitaries were excised and incubated individually.

To preclude the effects of fasting in the postoperative period, and hypoglycemia in animals which were treated with insulin (see below), glucose was administered to all of the rats subcutaneously. A total dose of $0.5 \mathrm{~g}$ glucose per $100 \mathrm{~g}$ body weight was administered as 10 per cent glucose in water in three divided doses at 6-hour intervals during the 20-hour postoperative period. The last injection was routinely administered 1 to 2 hours prior to sacrifice.

Some of the pancreatectomized animals were treated with insulin during the postoperative period. Therapy consisted of $0.5 \mathrm{U}$ of protamine zinc insulin and $0.5 \mathrm{U}$ of regular insulin subcu- 


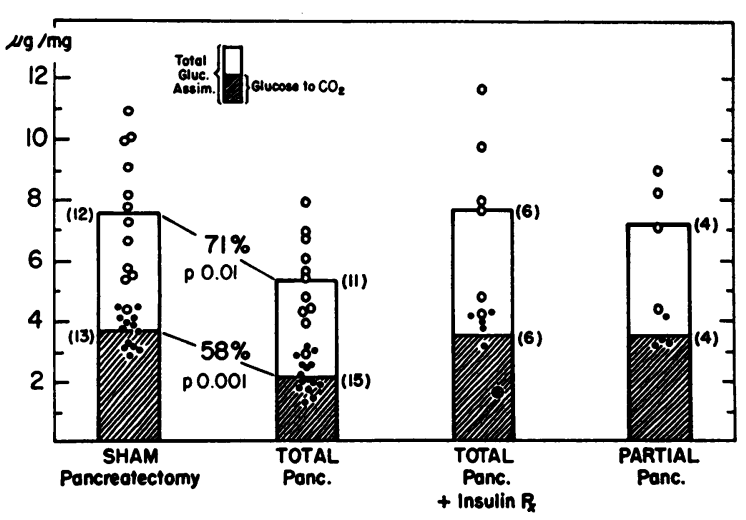

Fig. 2. Total assimilation of GLUCOSE AND MicroGRAMS PER MILLIGRAM OF GLUCOSE-U-C ${ }^{14}$ OXIDIZED TO $\mathrm{C}^{14} \mathrm{O}_{2}$ DURING INCUBATION OF SINGLE ANTERIOR PITUITARIES REMOVED FROM RATS 20 HOURS AFTER SURGICAL MANIPUlation. Mean glucose assimilation is indicated by the total heights of the bars; the shaded areas denote mean values for glucose oxidation to $\mathrm{CO}_{2}$. Individual values for these parameters are indicated by the open and closed symbols, respectively. The single circled value in the totally pancreatectomized, insulin-treated group represents the result in the animal in whom normoglycemia was not restored by therapy (see text). Mean values for the percentile reductions in glucose utilization by the totally pancreatectomized rats and the statistical significance of these changes are indicated on the illustration. Numbers in parentheses indicate the number of animals in each category.

taneously at 5 hours and $0.1 \mathrm{U}$ of regular insulin at 18 hours after operation.

Measurements of plasma glucose were employed to assess the severity of the experimental diabetes and the adequacy of the replacement therapy with insulin. Values were obtained 5 hours following surgery (i.e., prior to the administration of the first dose of glucose and before the exhibition of insulin in the insulin-treated group) and at sacrifice (i.e., following three doses of glucose and insulin therapy in some animals). Plasma glucose

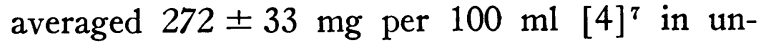
treated pancreatectomized rats 5 hours after operation and $762 \pm 110 \mathrm{mg}$ per $100 \mathrm{ml}$ [15] at sacrifice following three doses of glucose. In five of six similar pancreatectomized rats (mean plasma

${ }^{7}$ Throughout this paragraph, the blood sugar values given are expressed as the mean \pm standard error in the respective groups. Brackets denote the number of animals in each experimental group from which blood was sampled. Five-hour specimens of blood were obtained from the tail vein. Bloods at sacrifice were collected from the neck following decapitation of the animals. glucose $270 \pm 29$ [6], 5 hours postoperatively), the exhibition of insulin in association with glucose reduced blood sugar to an average of $75 \pm 11$ $\mathrm{mg}$ per $100 \mathrm{ml}$ [5] at sacrifice. Insulin therapy was inadequate in the sixth animal and final blood sugar was $187 \mathrm{mg}$ per $100 \mathrm{ml}$. Significant abnormalities in blood sugar were not observed at any time intervals in the partial or sham pancreatectomized groups. Respective values for blood sugar in these groups were $84 \mathrm{mg}$ per $100 \mathrm{ml}$ [2] and $58 \pm 4 \mathrm{mg}$ per $100 \mathrm{ml}$ [5] 5 hours following surgery, and $107 \pm 5 \mathrm{mg}$ per $100 \mathrm{ml}$ [4] and $102 \pm 6 \mathrm{mg}$ per $100 \mathrm{ml}$ [13] at sacrifice.

Patterns of carbohydrate metabolism observed during the in vitro incubations of individual anterior pituitaries are summarized in Figures 2 and 3 . In untreated pancreatectomized rats, total assimilation of glucose, oxidation of glucose-U-C $\mathrm{C}^{\mathbf{1 4}}$ (Figure 2) and conversion of glucose- $\mathrm{U}-\mathrm{C}^{14}$ to fatty acids (Figure 3 ) by AP, were significantly reduced as compared to values obtained with $\mathrm{AP}$

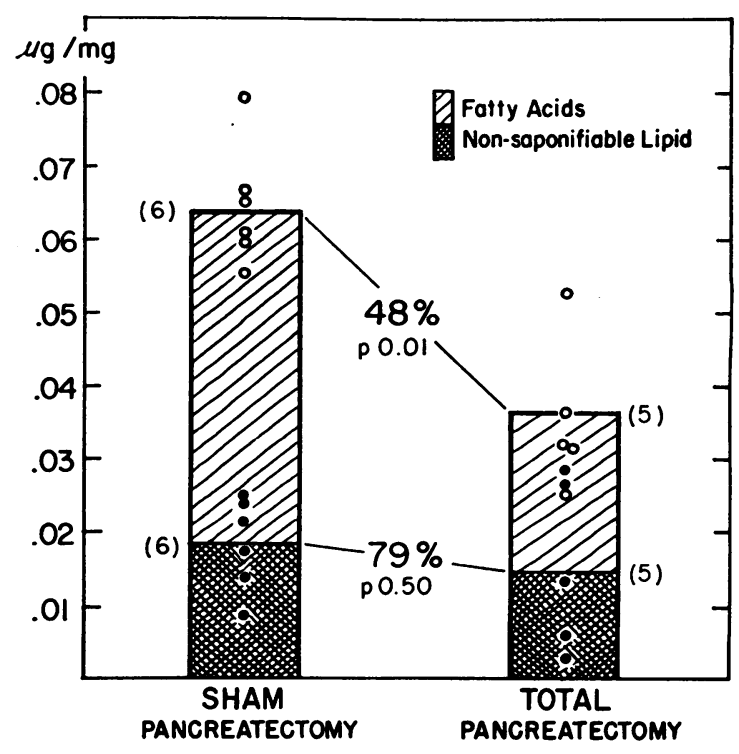

Fig. 3. INCORPORATION OF GLUCOSE-U-C ${ }^{14}$ INTO NONSAPONFIABLE LIPIDS AND FATTY ACIDS DURING INCUBATION OF SINGLE ANTERIOR PITUITARIES REMOVED FROM RATS 20 HOURS AFTER SURGICAL MANIPULATION. The total heights of the bars represent the sum of the micrograms per milligram of glucose-U-C $\mathrm{C}^{14}$ recovered as fatty acids (diagonal lines) and nonsaponifiable lipids (cross-hatched). Mean values for the percentile reductions in lipogenesis in totally pancreatectomized rats and the statistical significance of these changes are indicated on the illustration. Numbers in parentheses denote the number of animals in each category. 
TABLE $V$

The effect of severe operative trauma upon the glucose metabolism of rat anterior pituitary

\begin{tabular}{|c|c|c|c|c|}
\hline Operative group & Rat & & Glucose assimilation & $\mathrm{C}^{14} \mathrm{O}_{2}$ \\
\hline \multicolumn{5}{|l|}{ A. Pancreatectomized rats } \\
\hline \multicolumn{5}{|l|}{$\begin{array}{c}\text { Pancreatectomized }+ \\
\text { Complications }\end{array}$} \\
\hline \multirow[t]{2}{*}{$\begin{array}{c}\text { Pancreatectomized }+ \\
\text { No complications }\end{array}$} & & Mean $\pm \mathrm{SE}$ & $5.63+-1.23[7]^{*}$ & $2.16 \pm 0.14[10]$ \\
\hline & & Mean $\pm \mathrm{SE}$ & $4.51+-1.65[4]$ & $2.32 \pm 0.15[5]$ \\
\hline \multicolumn{5}{|l|}{ B. Control rats } \\
\hline Bile peritonitis & $\begin{array}{l}1 \\
2 \\
3 \\
4\end{array}$ & Mean $\pm \mathrm{SE}$ & $\begin{array}{r}9.78 \\
8.57 \\
11.25 \\
9.09 \\
9.67 \pm 0.58\end{array}$ & $\begin{array}{l}4.48 \\
4.31 \\
3.99 \\
3.92 \\
4.18 \pm 0.13\end{array}$ \\
\hline $\begin{array}{l}\text { Intra-abdominal } \\
\text { hemorrhage }\end{array}$ & $\begin{array}{l}1 \\
2 \\
3 \\
4\end{array}$ & Mean $\pm \mathrm{SE}$ & $\begin{array}{r}11.26 \\
8.75 \\
10.00 \\
11.46 \\
10.37 \pm 0.63\end{array}$ & $\begin{array}{l}3.88 \\
3.98 \\
4.17 \\
4.14 \\
4.04 \pm 0.06\end{array}$ \\
\hline Sham & $\begin{array}{l}1 \\
2 \\
3\end{array}$ & Mean $\pm \mathrm{SE}$ & $\begin{array}{r}9.53 \\
8.45 \\
10.24 \\
9.41 \pm 0.52\end{array}$ & $\begin{array}{l}3.25 \\
4.11 \\
3.78 \\
3.71 \pm 0.25\end{array}$ \\
\hline
\end{tabular}

* Number of animals in brackets.

from sham-operated animals. The values for these three parameters of glucose metabolism were reduced to $71(\mathrm{p}=0.01), 58(\mathrm{p}=0.001)$ and 48 $(\mathrm{p}=0.01)$ per cent of the control values, respectively. Reduction of glucose metabolism was not observed with AP derived from the partially pancreatectomized rats or the five pancreatectomized rats in which replacement therapy with insulin had been adequate (Figure 2).

Many of the pancreatectomized animals displayed operative complications consisting of bile peritonitis or intra-abdominal hemorrhage. Although these phenomena did not appear to alter AP metabolism in pancreatectomized animals (Table V, A), separate experiments were performed to assess the effects of operative complications independent of disturbances in carbohydrate metabolism. Bile peritonitis or intra-abdominal hemorrhage with shock was produced in normal animals, and, after 20 hours, AP glucose metabolism was compared with that of sham-operated rats (Table V, B). Despite oliguria and prostration comparable in severity to that seen in pan- createctomized animals with operative complications, the AP metabolism of glucose was indistinguishable from that of the concurrently examined sham-operated control population. Thus, the observed depression in the metabolism of glucose by AP of pancreatectomized rats cannot be ascribed to operative trauma or shock.

The occurrence of operative complications in two-thirds of the pancreatectomized rats also afforded a means of assessing whether the derangement of pituitary metabolism was a primary consequence of hypophyseal insulin deprivation or whether it was secondary to generalized metabolic disturbances (i.e., acidosis, ketosis, triglyceridemia and so forth) resulting from insulin deprivation elsewhere. Gross stigmata of aberrant lipid metabolism (24) were not so pronounced in the animals with operative complications and surgical shock (25). Correlations were attempted by visually grading 0 to $4+: a$ ) fatty infiltration of the liver, $b$ ) turbidity of plasma, and $c$ ) semiquantitative chemical estimation of plasma "acetoacetic acid and acetone" (26). The metabolism of 
glucose by excised AP did not correlate in severity with any of these indices of generalized metabolic abnormalities.

In the above studies of experimental diabetes, values for glucose assimilation by AP from shamoperated control animals (Figure 2 and Table V) were considerably lower than the glucose uptakes observed during incubation of pooled hemisected AP from normal fed rats in media similarly containing $2 \mathrm{mg}$ per $\mathrm{ml}$ of glucose (Experiments 1118, Table IV). The reasons for this are not immediately apparent, especially since comparable differences did not obtain in the evolution of $\mathrm{C}^{14} \mathrm{O}_{2}$ (Figure 2 and Table V vs Table IV). However, in any analysis; it should be noted that experimental conditions were not identical. Thus, the studies differed not only in the dietary and manipulative preparation of donor animals but also in the volume of suspending medium (i.e., 0.3 vs 1.2 $\mathrm{ml}$ ), in the nature of suspending medium (i.e., plain $\mathrm{KRB}$ vs $\mathrm{KRB}+40 \mu \mathrm{g}$ albumin per $\mathrm{ml}$ ), and in the status of the tissues (i.e., intact vs hemisected AP). That such subtle factors might influence assimilative function is suggested by the demonstration by Roberts and Keller (7) of appreciable anaerobic glycolysis in rat AP. In any event, the findings would suggest that normal values for glucose assimilation by surviving prep- arations of AP can only be defined within a rigid framework of given in vitro experimental conditions.

B. Alloxanized rats. Chronic diabetes mellitus was induced in rats by the subcutaneous administration of $125 \mathrm{mg}$ alloxan monohydrate per $\mathrm{kg}$ body weight after a 24 -hour fast. Six weeks after administration of alloxan, 12 diabetic rats were paired by weight and fasting blood glucose concentration (Table VI). Thereafter, all rats were allowed food ad lib. and one member of each pair was treated with insulin for the 7 days preceding sacrifice. Treatment consisted of single daily injections of 1.0 to $3.0 \mathrm{U}$ of protamine zinc insulin per $100 \mathrm{~g}$ body weight adjusted to prevent urine glucose concentrations above 0.5 per cent. Two hours prior to sacrifice, the treated rats were given 4.0 $\mathrm{U}$ of regular insulin subcutaneously. The untreated rats gained little weight and exhibited uniformly high plasma glucose levels at sacrifice. The treated animals gained an average of $10 \mathrm{~g}$ body weight per day and had normal or moderately hypoglycemic levels of blood glucose at sacrifice (Table VI).

At the end of the treatment period, the anterior pituitary glands from all of the rats were incubated individually with glucose- $\mathrm{U}_{-} \mathrm{C}^{14}$. The mean glucose assimilation and oxidation of glucose- $\mathrm{U}-\mathrm{C}^{14}$

TABLE VI

The metabolism of glucose by anterior pituitary in untreated and treated alloxan-diabetic rats

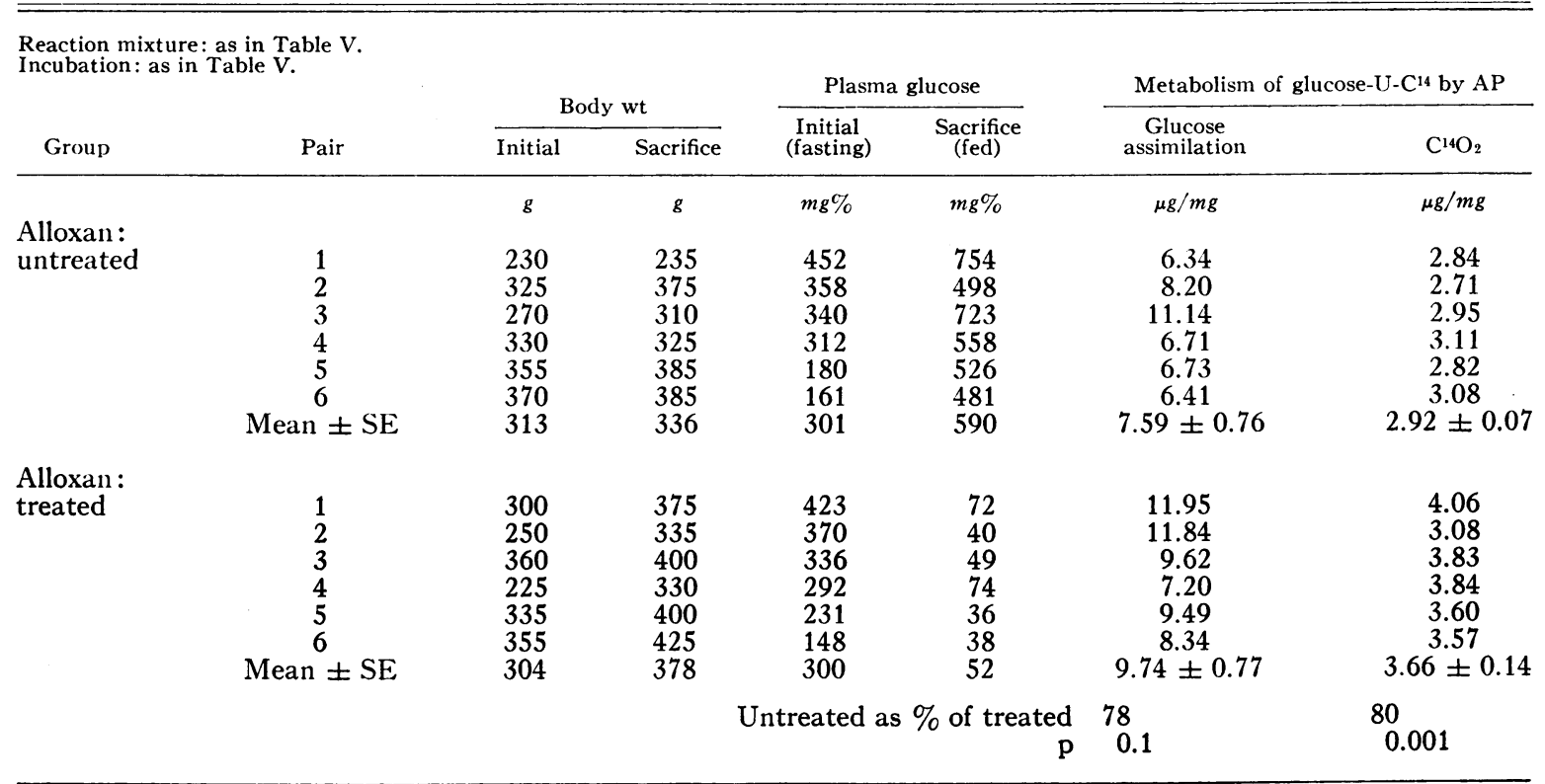


to $\mathrm{C}^{14} \mathrm{O}_{2}$ by $\mathrm{AP}$ in untreated rats were 78 and 80 per cent, respectively, of the corresponding values in the treated group. The difference in $\mathrm{C}^{14} \mathrm{O}_{2}$ production was statistically significant $(\mathrm{p}=0.001)$.

In this, as in all other studies, metabolic activity in vitro has been related to a unit of mass, i.e., milligrams of anterior pituitary. The validity of comparing glands of different weight in this fashion was examined by plotting oxidation of glucose to $\mathrm{C}^{14} \mathrm{O}_{2}$ as a function of total AP weight (Figure 4). This indicated that activity per unit mass within each experimental group remained relatively constant despite wide variations in pituitary mass. Thus, at any single level of AP weight, the total activity of AP from treated or sham-operated animals exceeded the values observed in untreated diabetic rats. Since AP : total body weight ratios in the animals with experimental diabetes mellitus did not significantly deviate from normal, it may be inferred that reduction of activity per unit mass represented a valid index of reduction in total pituitary activity.

\section{DISCUSSION}

In establishing that a tissue is responsive to insulin and that the responsiveness is of physiological significance, multiple criteria should be fulfilled. First and ideally, one should be able to elicit a direct effect with insulin in vitro. This desideratum need not always obtain. For example, although liver slices do not usually respond to added insulin $(27,28)$, mounting evidence would indicate that the hormone can directly modify hepatic function in the intact animal (29, 30 ) or in the perfused liver (31). Furthermore, even when an action of insulin can be demonstrated in vitro, the relationship between dose and response need not equate with sensitivity to insulin in vivo. Many tissues contain soluble insulindegrading enzymes which are leached into the suspending medium during incubation of cut preparations $(32,33)$. Recent work in this laboratory has indicated that the resultant extracellular proteolysis of the added insulin diminishes its manifest effectiveness upon the incubated tissue (34). Moreover, besides such leaching artifacts, one might anticipate that the response of an insulinsensitive tissue to exogenous insulin in vitro could be inversely conditioned by its exposure to endogenous insulin prior to excision from the donor

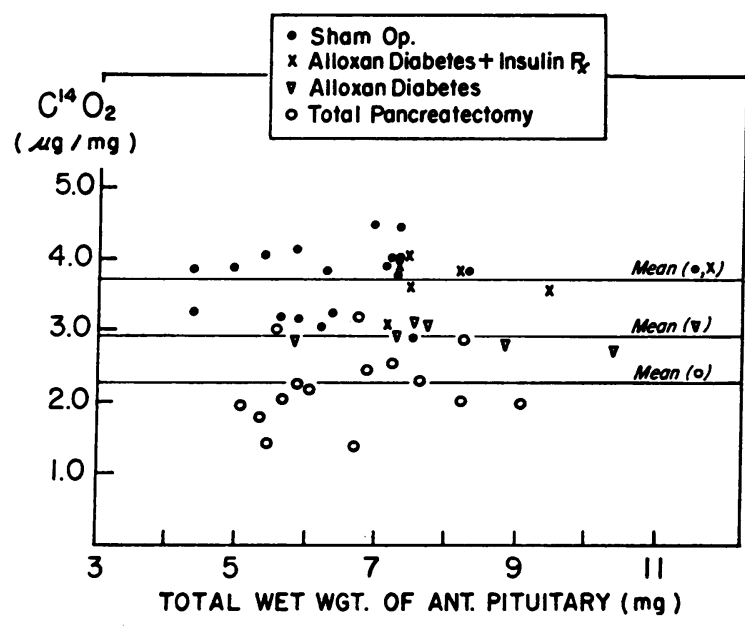

Fig. 4. THE RELATIONSHIP BETWEEN tOTAL ANTERIOR PITUITARY WEIGHT AND OXIDATION OF GLUCOSE-U-C $C^{14}$ TO $\mathrm{C}^{14} \mathrm{O}_{2}$ PER MILLIGRAM OF INCUBATED ANTERIOR PITUITARY TISSUE. Symbols denote individual values in the shamoperated, diabetic, and treated diabetic categories. Horizontal lines denote mean values for glucose oxidation in the various groups.

animal. In the present studies, experimental design was influenced by these considerations. Thus, because "insulinase" (35) and other proteases (36) are present in anterior pituitary, and because hypophyseal vascularity may be sufficient to effect near maximal delivery of insulin to AP in the intact animal, "supramaximal" doses of 1 U per $\mathrm{ml}$ were employed for investigation of insulin addition in vitro. Precise dose-response relationships were not examined. Rather, attempts were made to assess only whether anterior pituitary is or is not capable of directly responding to insulin. Within this framework, unequivocal effects were obtained with slices of calf AP, and smaller, although still statistically significant, changes were observed with pooled hemisected AP from normal fed rats. Insofar as added insulin definitely affected the carbohydrate metabolism of surviving pituitary tissue, the in vitro studies demonstrated the existence of adenohypophyseal components capable of direct hormonal modification. However, direct response to pharmacological quantities of insulin need not connote physiological significance nor justify extrapolations concerning the contribution of insulin to the normal function of that tissue in the intact animal. Such conclusions require the demonstration of metabolic defects in the "insulin-responsive" tissue following withdrawal of insulin in vivo. 
Accordingly, to fulfill this second criterion, pituitaries from animals with experimental diabetes were examined. Carbohydrate metabolism was reduced 30 to 50 per cent below control values in anterior pituitaries derived from rats rendered acutely aninsulinemic by total pancreatectomy. The magnitude of this derangement approaches the degree of impaired glucose utilization which has been observed in such classically insulinresponsive tissues as diaphragm $(37,38)$ or adipose tissue (39) from diabetic rats. Furthermore, the defect correlated best with the degree of insulin lack rather than of operative trauma. Thus, it was not observed in partially pancreatectomized animals or in rats with surgically induced shock or hypovolemia in which pancreatic structure was preserved. Moreover, in the alloxanized animals in which absolute insulin deficiency was not achieved (as judged by their limited inanition and their survival in the untreated state), reduction of pituitary carbohydrate metabolism was not as profound. It would seem unlikely that the hypophyseal "biochemical lesions" in the diabetic animals represented merely secondary consequences of ketonemia, acidosis or lipemia, since significant differences could not be demonstrated between animals in which total pancreatectomy was uncomplicated, and animals in which circulatory collapse precluded the full development of post-pancreatectomy ketogenesis (25) or lipid mobilization. Indeed, the manifest association between insulin deprivation in vivo and deterioration of pituitary carbohydrate metabolism reinforces the significance of the small effects which were obtained by directly adding insulin to normal rat AP in vitro.

Theoretically, for any given tissue, the third criterion of physiological insulin-responsiveness should consist of the correction of metabolic defects by the in vivo administration of insulin to insulin-deficient animals. In the present studies with anterior pituitary, this objective was also fulfilled. Exhibition of exogenous insulin within hours following total pancreatectomy completely prevented the decline of hypophyseal carbohydrate economy. Moreover, in animals with chronic hypoinsulinism, i.e., the alloxanized rat, therapy with insulin enhanced the metabolic performance of pituitary tissue. Although precise temporal relationships were not fully documented, the re- versibility would indicate that permanent alterations in the carbohydrate metabolism of the anterior pituitary did not result from 6 weeks of partial insulin deprivation.

Thus, by the most rigid criteria, it would appear that the anterior pituitary must be included in the growing list of insulin-responsive tissues (40). Indeed, the present demonstration that intrahypophyseal utilization of glucose will respond to insulin in vitro, deteriorates following insulin withdrawal in vivo, and can be restored by insulin administration to insulin-deficient animals in vivo, would suggest that the anterior pituitary must be considered "diabetic" in the syndrome of diabetes mellitus. For the moment, translation of the findings into more definitive implications for normal homeostasis within the pituitary or pathological aberrations in spontaneous diabetes mellitus must be deferred. First, since the cellular population of the anterior pituitary is not homogeneous, it remains to be defined which cell types are responsive to insulin. Possibly, only a limited proportion might be affected or response-thresholds of various elements might differ considerably. That some cellular components may be altered is suggested by the reported occurrence of basophilic changes in the pituitaries of totally pancreatectomized dogs (41). Second, the precise relationship between hypophyseal carbohydrate metabolism and intrapituitary turnover of hormones remains to be elucidated. By analogy to other systems (42-44), the pathways which have been described in the present studies for the storage of glucose, the mobilization of glycogen, and the oxidation of glucose-6-phosphate within the pituitary could subserve important functions in selective or generalized hormonogenesis. Derangement of these pathways and diminished energy generation through impaired oxidation of glucose might not only alter the balanced biosynthesis of known pituitary hormones, but could even promote the formation of abnormal, biologically potent protein or peptide principles. However, elaboration of anterior pituitary hormones also entails storage, release, and responsiveness to peripheral as well as to suprahypophyseal regulators. It is conceivable (45) that any or all of these processes might be conditioned by pituitary carbohydrate metabolism.

At present, there seems to be no compelling 
clinical evidence for derangement of pituitary function in spontaneous diabetes mellitus. On the other hand, the relatively crude methods which have been available for such evaluation do not constitute compelling reasons for discarding the possibility. The present studies with laboratory animals highlight the critical need for re-examination of the possible interrelationships and afford a feasible experimental approach for this type of inquiry.

\section{SUMMARY}

1. Pathways of carbohydrate metabolism have been examined in surviving preparations of normal calf and rat anterior pituitary. Mechanisms for active glycogen turnover and glucose oxidation via the hexose-monophosphate shunt in vitro have been demonstrated. Anterior pituitaries from both species responded to the direct addition of insulin to the suspending media.

2. Micro-methods have been developed for incubation of single rat anterior pituitaries. With this technique, it has been demonstrated that hypophyseal carbohydrate metabolism is significantly reduced in anterior pituitaries excised from rats rendered acutely insulin-deficient by total pancreatectomy or chronically diabetic by alloxanization. The phenomenon could not be attributed to such systemic manifestations of insulin deprivation as ketoacidosis and could not be duplicated by comparable degrees of surgical trauma in animals in which pancreatic function was preserved. The derangement of hypophyseal glucose utilization in rats with experimental diabetes could be prevented or reversed by treatment with replacement quantities of insulin in vivo.

3. The data indicate that the anterior pituitary is responsive to insulin and that intrahypophyseal carbohydrate metabolism in the intact animal may be conditioned by the availability of insulin. The significance of insulin dependency in terms of the normal endocrine function of the anterior pituitary and pituitary status in spontaneous diabetes mellitus remains to be elucidated.

\section{ACKNOWLEDGMENTS}

The excellent technical assistance of Mr. Edward C. Saef and Miss Martha F. McMullen are gratefully acknowledged. Calf pituitary glands were obtained through the kind cooperation of the New England Dressed
Meat and Wool Co., Somerville, Mass. The authors are greatly indebted to Dr. Robert O. Scow for his patient instruction in the technique of total pancreatectomy in the rat.

\section{REFERENCES}

1. Houssay, B. A., and Biasotti, A. The hypophysis, carbohydrate metabolism and diabetes. Endocrinology 1931, 15, 511.

2. Evans, H. M., Meyer, K., Simpson, M. E., and Reichert, F. L. Disturbance of carbohydrate metabolism in normal dogs injected with hypophyseal growth hormone. Proc. Soc. exp. Biol. (N. Y.) 1932, 29, 857.

3. Young, F. G. Glycogen and the metabolism of carbohydrate. Lancet 1936, 2, 297.

4. Long, C. N. H., and Lukens, F. D. W. The effects of adrenalectomy and hypophysectomy upon experimental diabetes in the cat. J. exp. Med. 1936, 63, 465.

5. De Bodo, R. C., and Altszuler, N. Insulin hypersensitivity and physiological insulin antagonists. Physiol. Rev. 1958, 38, 389.

6. Victor, J., and Andersen, D. H. The effects of oestrus and spaying on pituitary metabolism. Amer. J. Physiol. 1936, 115, 130.

7. Roberts, S., and Keller, M. R. Respiration and glycolysis in the hypophysis and hypothalamus of the rat. Arch. Biochem. 1953, 44, 9.

8. Levey, H. A., and Roberts, S. Influence of thyroid function on the metabolism of the anterior pituitary gland. Amer. J. Physiol. 1957, 189, 86.

9. Chain, E. B. Recent studies on carbohydrate metabolism. Brit. med. J. 1959, II, 709.

10. Rafaelsen, O. J. Action of insulin on isolated rat spinal cord. Lancet 1958, 2, 941.

11. Smith, P. E., and Smith, I. P. The topographical separation in the bovine anterior hypophysis of the principle reacting with the endocrine system from that controlling general body growth, with suggestions as to the cell types elaborating these excretions. Anat. Rec. 1923, 25, 150.

12. Smelser, G. K. Differential concentration of hormones in the central and peripheral zones of the bovine anterior pituitary gland. Endocrinology 1944, 34, 39.

13. Renold, A. E., Martin, D. B., Dagenais, Y. M., Steinke, J., Nickerson, R. J., and Sheps, M. C. Measurement of small quantities of insulin-like activity using rat adipose tissue. I. A proposed procedure. J. clin. Invest. 1960, 39, 1487.

14. Nelson, N. A photometric adaptation of the Somogyi method for the determination of glucose. J. biol. Chem. 1944, 153, 375.

15. Huggett, A. St. G., and Nixon, D. A. Use of glucose oxidase, peroxidase, and o-dianisidine in determination of blood and urinary glucose. Lancet 1957, 2, 368.

16. Freinkel, N., and Ingbar, S. H. The effects of the arylsulfonylureas on the respiratory activity and 
glucose metabolism of isolated rabbit kidney cortex. Endocrinology 1959, 64, 1002.

17. Good, C. A., Kramer, H., and Somogyi, M. The determination of glycogen. J. biol. Chem. 1933, 100, 485.

18. Umbreit, W. W., Burris, R. H., and Stauffer, J. F. Manometric Techniques, 3rd ed. Minneapolis, Burgess Publishing, 1957, p. 278.

19. Folch, J., Lees, M., and Sloane Stanley, G. H. A simple method for the isolation and purification of total lipides from animal tissues. J. biol. Chem. 1957, 226, 497.

20. Chernick, S. S., Masoro, E. J., and Chaikoff, I. L. The in vitro conversion of $\mathrm{C}^{i 4}$-labeled glucose to fatty acids. Proc. Soc. exp. Biol. (N. Y.) 1950, $73,348$.

21. Goodner, C. J., and Freinkel, N. Unpublished observations.

22. Finney, D. J. Statistical Methods in Biological Assay. New York, Hafner, 1952, pp. 38-39.

23. Scow, R. O. "Total" pancreatectomy in the rat: Operation, effects, and postoperative care. Endocrinology 1957, 60, 359.

24. Scow, R. O., Wagner, E. M., and Cardeza, A. The effect of hypophysectomy on the insulin requirement and response to fasting of "totally" pancreatectomized rats. Endocrinology 1957, 61, 380.

25. Engel, F. L., and Hewson, K. Fatty acid and ketone metabolism during hemorrhage and shock in the rat. Proc. Soc. exp. Biol. (N. Y.) 1953, 83, 608.

26. Joslin, E. P., Root, H. F., White, P., and Marble, A. The Treatment of Diabetes Mellitus, 10 th ed. Philadelphia, Lea \& Febiger, 1959, p. 208.

27. Brady, R. O., and Gurin, S. Biosynthesis of labeled fatty acids and cholesterol in experimental diabetes. J. biol. Chem. 1950, 187, 589.

28. Renold, A. E., Hastings, A. B., Nesbett, F. B., and Ashmore, J. Studies on carbohydrate metabolism in rat liver slices. IV. Biochemical sequence of events after insulin administration. J. biol. Chem. 1955, 213, 135.

29. Madison, L. L., Combes, B., Adams, R., and Strickland, W. The physiological significance of the secretion of endogenous insulin into the portal circulation. III. Evidence for a direct immediate effect of insulin on the balance of glucose across the liver. J. clin. Invest. 1960, 39, 507.

30. Williams, W. R., Hill, R., and Chaikoff, I. L. Portal venous injection of insulin in the diabetic rat: Time of induction of changes in hepatic lipogenesis, cholesterogenesis, and glycogenesis. J. Lip. Res. 1960, 1, 236.
31. Haft, D. E., and Miller, L. L. Alloxan diabetes and demonstrated direct action of insulin on metabolism of isolated perfused rat liver. Amer. J. Physiol. 1958, 192, 33.

32. Narahara, H. T., and Williams, R. H. Effect of protein added in vitro upon insulin degradation and glucose uptake by muscle. J. biol. Chem. 1958, 233, 1034.

33. Piazza, E. U., Goodner, C. J., and Freinkel, N. A re-evaluation of in vitro methods for insulin bioassay. Diabetes 1959, 8, 459.

34. Freinkel, N., Goodner, C. J., and Litonjua, A. The relationship between degradation of extracellular insulin and insulin action in vitro. In preparation.

35. Narahara, H. T., and Williams, R. H. Degradation of insulin- $\mathrm{I}^{131}$ by an extract of anterior pituitary gland. Amer. J. Physiol. 1958, 193, 476.

36. Ellis, S. Pituitary proteinase I: Purification and action on growth hormone and prolactin. J. biol. Chem. 1960, 235, 1694.

37. Krahl, M. E., and Cori, C. F. The uptake of glucose by the isolated diaphragm of normal, diabetic, and adrenalectomized rats. J. biol. Chem. 1947, 170, 607.

38. Villee, C. A., and Hastings, A. B. The metabolism of $\mathrm{C}^{14}$-labeled glucose by the rat diaphragm in vitro. J. biol. Chem. 1949, 179, 673.

39. Winegrad, A. I., and Renold, A. E. Studies on rat adipose tissue in vitro. I. Effects of insulin on the metabolism of glucose, pyruvate, and acetate. J. biol. Chem. 1958, 233, 267.

40. Renold, A. E., Ashmore, J., and Hastings, A. B. Regulation of carbohydrate metabolism in isolated tissues. Vitam. and Horm. 1956, XIV, 139.

41. Gregory, R. L., Drager, G. A., Tsai, S. Y., and May, L. G. The effect of diabetes of pancreatectomy on the pituitary cytology of dogs. Endocrinology 1956, 58, 79.

42. Haynes, R. C., Jr., and Berthet, L. Studies on the mechanism of action of the adrenocorticotropic hormone. J. biol. Chem. 1957, 225, 115.

43. Péron, F. G., and Koritz, S. B. On the exogenous requirements for the action of $\mathrm{ACTH}$ in vitro on rat adrenal glands. J. biol. Chem. 1958, 233, 256.

44. Wilson, J. D., and Siperstein, M. D. Studies on the relationship between glucose oxidation and intermediary metabolism. III. The influence of pyridine nucleotides on protein synthesis. J. clin. Invest. 1959, 38, 317.

45. Lawrence; A. M., Contopoulos, A. N., and Simpson, M. E. Pituitary and plasma bioassay for trophic hormones in the alloxan-diabetic rat. Proc. Soc. exp. Biol. (N. Y.) 1958, 99, 35. 